\title{
Studies on the European Hare. I. Moulting and Coloration
}

Badania nad zającem szarakiem. I. Linka i ubarwienie

\author{
[With 4 Figs. \& 3 Tables]
}

I. Introduction

II. Material and methods

III. Results of investigations . . . . . . . . . . . 219

1. Variations in coloration . . . . . . . 219

2. Moulting . . . . . . . . 223

3. Length and density of fur . . . . . . . . . 226

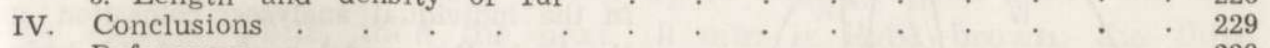

References : $: 2^{2} 229$

Streszczenie . . . . . . . . . . . . . 231

\section{INTRODUCTION}

The aim of this study is to contribute to a better knowledge of the course ta ken by moulting and variations in coloration in the hare (Lepus europaeus If a 11 a s, 1778) during the yearly cycle. The information on this problem so far to be found in literature is extremely scanty. O g n e v (1940) states: "The autumn moult of the hare in the Moscow district starts at the beginning of October and finishes at the end of November. The spring moult takes a more turbulent form, from April to the beginning of May".

Ge r a s i mow a $(1955 \mathrm{~b})$ refers to the autumn moult of the hare. In another study this authoress (1955 a) discusses the density and length of the fur of hares from different parts of the Soviet Union, and finds that the summer skin is thicker than the winter one.

K orneyev (1960) gives the information that in the Ukraine moulting in the hare lasts throughout the whole of the spring-summer period. During this time the skin takes on a blueish-grey colour, thickens and remains in this condition until the late autumn. When the winter coat grows in the autumn, the skin whitens and remains light in colour until the spring moult. The direction taken by the moult, according to $\mathrm{K}$ or neyev, both in autumn and spring is identical, i.e. from the back tho the abdomen. The author considers the whole of these processes as one moult, although $\mathrm{Hews}$ on (1963) distinguishes two moulting periods. 
The question of the moult in other species of hare has been more widely discussed in literature, the following authors having written about the spring and autumn moult of Lepus timidus L.: Ognev (1940), C o u t u r i e r (1955), Lind (1961), Dimidov \& Popov (1961), Wostson (1963) and Kryltzov (1962). Bider (1961) discussed the moult in Lepus americanus Erxleben, 1777 .

\section{MATERIAL AND METHODS}

A total of 611 skins of hares were used for the investigations, and came from the Poznan province, where they were collected during the period from December 1958 to February 1960. A further 28 winter skins from the Bialystok province were examined for purposes of comparing the coloration, and length and density of the fur.

A separate analysis of coloration was made for each skin, then the whole of the material was spread out in the open, on a sunless day, which made it possible

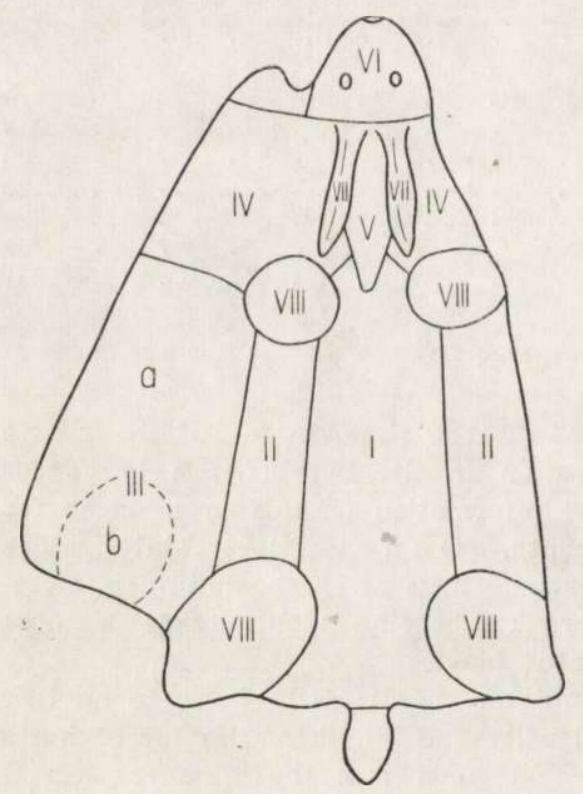

Fig. 1. Zone of moulting in L. europaeus. to examine the range of variations in the whole material. All the skins were cut along the borderline between the right side and the belly. The following characters were taken into consideration in the individual analyses: coloration of the back, the caudal region of the body above the tail, the sides, the occipitonuchal region, and in certain cases the upper breast. If the coloration of the head, ears, cheeks, caudal part of the body and lumbar region differed from the averafge then after description sections of the skin were taken from these places as specimens. When describing variations in coloration during the seasons attention was primarily paid to the colour of the back, sides and caudal part of the body. The Ostwald (1939) scale was used here, simultaneously giving the terms used by Ridgway (1912) (according to $\mathrm{Zimmermann}$, 1952).

The moult was traced in all the specimens, taking into consideration the change in the colour of the skin, growth, falling out and splitting of the hairs. In view of the fact that the moult takes place in certain parts of the body often independently of each other, the following zones were distinguished: back, sides, belly, upper chest (at the base of the neck), occipito-nuchal region (the wedge of different fur stretching from the ears almost to the scapulae), head, ear, cheek, rump and scapula (Fig. 1). The zones distinguished approximately correspond to the division into zones of the moult in the rabbit given by Gedy min

(1954). 
The length and density of the fur on the parts of the body under discussion also vary. Measurements were made of the length of hair on 88 hares: 30 specimens (15 $\sigma^{\top} \sigma^{\top}$ and 15 $\circ$ o $)$ from January 1959 and 30 specimens (15 $o^{\pi} o^{x}$ and $15 \circ \circ$ ) from July 1959, all from the Poznań province, and 28 specimens (15 $\sigma^{\top} \sigma^{\top}$ and 13 우) from December 1959 and January 1960 from the Bialystok province. Measurements were made with Napier compasses on sections of skin measuring about $1.5 \times 4.0 \mathrm{~cm}$. The sections were always taken from the approximate centre of the zones of the body given above. Measurements were made, of the guard and pile hairs and the fur (i.e. "Leithaar, Grannenhaar, Wollhaar" in terminology' used by Told, 1935). The hair was drawn vertically upwards from the section of skin and measurements made of about 10 hairs of each kind, with accuracy up to $1 \mathrm{~mm}$.

Measurements of density of the hair consisted in counting groups on sections of skin measuring $5 \times 5 \mathrm{~mm}$, and in counting the number of hairs in groups consisting of three tufts.

\section{RESULTS OF INVESTIGATIONS}

\section{Varations in Coloration}

Accurate definition of colour in the European hare is difficult on account of the fact that there are five different colours in the pile hairs on the back ( $\mathrm{T}$ old t, 1935). Up to about $10 \mathrm{~mm}$ above the skin the hair is white, then the next $10 \mathrm{~mm}$ is light brown; the third section, approximately $10 \mathrm{~mm}$ long is black, the fourth - from 5 to 8 $\mathrm{mm}$, which gives the animal its main colour, a yellowish-clayey colour, and a 5 th $-3-5 \mathrm{~mm}$ in length forms the end of the hair and is black. Hares are encountered, however, which have no black ends on the pile hair. The variegated colour of the hair in this species occurs in other parts of the body also, but in such cases the ends of the hair are long enough to give a uniform and distinct shade to the given part of the body. It is only on the belly that the fur is of a uniform colour white (Blank), or dirty white. The variations in the coloration of the hare are further complicated by the fact that during the moulting jexiod the ends of the old hair on the back become brittle and split, as will be described later on.

Using Ostwald's colour tables (1939) as a basis, endeavour was made to give the most detailed description possible of the coloration of the hare's fur in order to enable other authors to determine differences of a zoogeographical character.

Five basic shades of colour of the back were distinguished (Fig. 2 A):

1. Tawny Olive (l e 3 ) - an even mixture of tawny-clayey-black.

2. Clay Colour (n e 3 ) - tawny-clayey-black with distinct predominance of the tawny-yellow colour, where the pile hair has very short black ends, or where such ends are entirely absent. 


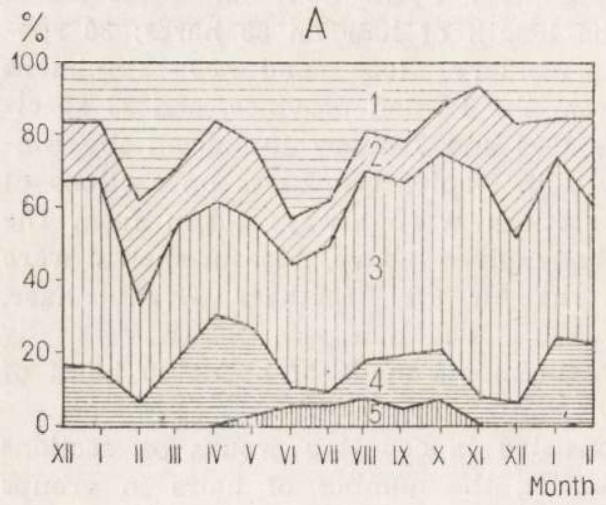

1. Tawny Olive (le 3), 2. Clay Colour (ne 3), 3. intermediate between Ochraceous Tawny (ne 3) and Tawny Olive (ng 3), or Buckthorn Brown (pe 3) and Dresden Brown ( $p g$ 3), 4. Tawny Olive (ng 3), 5. Tawny Olive (ie 3).

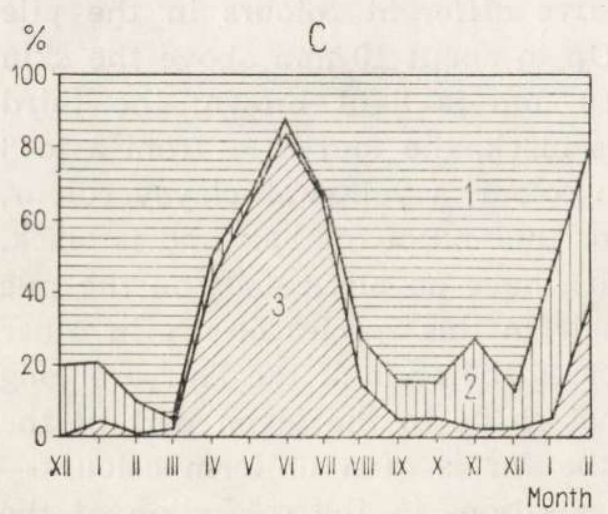

1. c-Grey Blanc, 2. c-Grey Blanc with Light Ochraceous Buff (ea 3 ) ends with brown ends of the guard hair, 3. e-Blanc Gray.
B

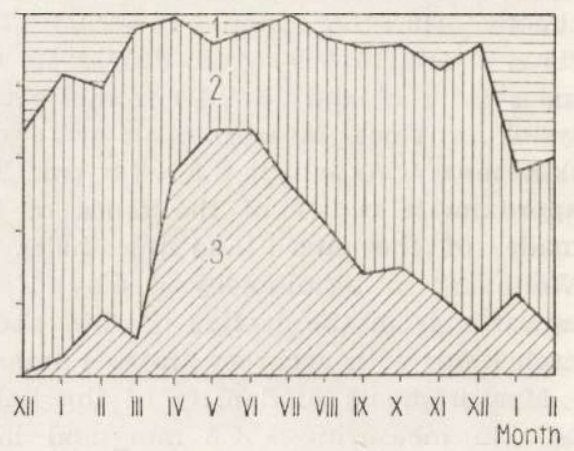

1. Vinacous Cinnamon (ic 4) - Cinnamon (ic 3) - Avellanous (ge 3), 2. Tawny Olive (ie 3 ), 3. Light Ochracous Buff (ea 3 ).

D

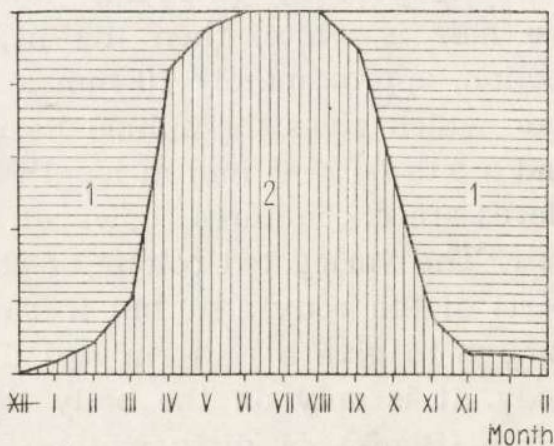

1. Dresden Brown (pg 3), Sudan Brown (pg 4) and Clay Colour (ne 3) with white ends, 2. Dresden Brown (pg 3), Sudan Brown (pg 4), Clay Colour (ne 3) and Tawny Olive (ie 3) without white ends.

Fig. 2. Percentage of different fur colours in European hare in the annual cycle. A - Back, B - Sides, C - Rump, D - Occipito-nuchal region.

3. An intermediate colour between Ochraceous Tawny (ne 3) and Tawny Olive ( $n g$ ), or between Buckthorn Brown ( $p$ e 3) and Dresden Brown ( $p g 3$ ) - a tawny-clayey-black, with distinct predominance of the clay colour. 
4. Tawny Olive ( $n g$ 3) - tawny-clayey-black with predominance of the black colour, where the pile hair has long black ends.

5. Tawny Olive (i e 3) - clayey-dun, without trace of black in the prickly hairs - the fur of young hares ${ }^{1}$ ).

The shade termed Tawny Olive $(l e 3)$ therefore predominates in the summer season before the spring moult, while Tawny Olive (i e 3) occurs only in the summer. The colours Ochraceous Tawny ( $n$ e 3) and intermediate shades between Ochraceous Tawny (ne 3) and Tawny Olive ( $n g$ 3), and between Buckthorn Brown ( $p$ e 3) and Dresden Brown ( $p$ g 3) occur most intensely in the winter (November-February), the greatest percentage of individuals coming within the latter intermediate shades throughout the whole year. The shade Tawny Olive ( $n g 3$ ) exhibits greatest intensity from the beginning of the spring moult (March-May), when the ends of the winter hair, by this time brittle, begin to split, and first the yellowish-clay fourth section, and later the third black section of the pile hair appears on the surface, also the black ends of the newly-grown hair. A certain intensification of this colour can be seen in January and February in both years.

There are no fundamental differences in the colour of the back in hares from the Poznan and Bialystok provinces. During the winter the hares from the Bialystok province have more hairs with white ends, and are therefore slightly lighter in colour than the hares from the Poznań province.

The scale of variations in the colour of the sides is shown by Fig. 2 B. Three basic shades can be distinguished here:

1. From Vinaceous Cinnamon (ic 4), through Cinnamon (i c 3) to Avellanous ( $g$ e 3 ) - tawny-red to reddish-brown

2. Tawny Olive (i e 3 ) - dun-reddish brown and

3. Light Ochraceous Buff (e a 3) - tawny-dun to dun.

The light colours Vinaceous Cinnamon (ic 4), Cinnamon (ic 3) and Avellanous ( $g$ e 3 ) occur in a large percentage of hares during the winter. The curve of the dun-reddish brown colour Tawny Olive (i e 3) takes a similar course, and this colour occurs in the greatest percentage of individuals in both winter and summer. During the summer the reddish-brown colour almost disappears and a large percentage of the individuals become a tawny-dun, or even dun colour - Light Ochraceous Buff (e a 3 ).

1) Certain difficulties are presented by names of colours, since $n g 3$, ie 3 , le 3 in Ostwald's colour numeration has only one name according to $\mathrm{R} i \mathrm{dg}$ w a $\mathrm{y}$ - Tawny Olive, or, conversely': Ostwald's ne3 - after R i d g w a y Clay Colour. Isabella Colour and Ochraceous Tawny; Os tw ald's ca3 - Ridg w a y's - Pale Ochraceous Salmon, Pale Vinaceous Fawn; Ostwald's ea3 - Ridgwa y's - Pale Cellow Orange, Pinkish Buff, Warm Buff etc. 
During the winter period the sides of about $40 \%$ of the hares from the Białystok province are a pinkish-cinnamon colour - Drab ( $g$ a 3 ) to Pinkish Cinnamon ( $g$ c 3 ), this phenomenon not being encountered in hares from the Poznan province.

The caudal part of the body above the tail is basically ash-grey in colour, but here also three shades can be distinguished (Fig. 2c):

1. c-Grey Blanc acc. to Grey Scale - greyish-dun

2. c-Grey Blanc with long, light brown Light Ochraceous Buff (e a 3) ends to the guard hair - greyish-dun and

3. e-Blanc Grey - ash-grey or dirty grey.

The overwhelming predominance of the light grey hair (c-Grey Blanc) occurs in the winter months, while the dirty-grey hair (e-Blanc Grey) together with curliness of the fur, occurs during the summer months. The small percentage of individuals in which the grey colour is covered by the distinct brown shade of the ends of the guard hair, is greatest in the winter.

The seasonal variations in the colour of the hair in the occipito-nuchal region, which in principle is rust-brown-cinnamon, are characteristic. Individual variations are confined here to Dresden Brown and Orange Citrine (=pg 3), Sudan Brown ( $p g 4$ ), Clay Colour (ne 3) and Tawny Olive (i e 3). This last shade is not encountered in the winter. Seasonal variations consist in the short hair of the occipito-nuchal region not having ends in the summer, while in the winter over $90 \%$ of the individuals have hair with white ends (Fig. 2 D).

The coat on the belly is, as has already been mentioned, uniform in colour in both winter and summer - white (a-Blanc) passing gradually to a reddish-brown colour on the upper chest and dun-reddish brown on the sides.

The colour of the hair on the upper chest is uniform throughout the year - the summer hair is only shorter than the winter coat, more matt and it is more difficult to find the Cinnamon (i c 3) shade in it. This shade occurs in about $30 \%$ of the individuals during the winter. The other shades, i.e. Clay Colour ( $n$ e 3), Dresden Brown ( $p g$ 3) and Tawny Olive (i e 3 ) are encountered in individuals with either summer or winter coats.

The colours of the hair on the upper side of the head and insides of the ears are almost uniformly tawny-clayey-black, most similar to the colour of the hair on the back in shades ranging from Clay Colour ( $n$ e 3) through Dresden Brown ( $p g$ 3) to Tawny Olive ( $\mathrm{g}$ 3). The colour of the fur on the other parts of the ears agrees with the description given by Ognev (1940) and Korneyev (1960). About 
$10 \%$ of the hares have a white "star" on the forehead, more often encountered in the winter.

The cheeks have a different colours to that of the top of the head. In principle they are far lighter, and brighten in colour in the winter to a pinkish-cinnamon shade - Drab $(g a 3)$ and Pinkish Cinnamon ( $g c 3$ ) through light yellowish - Drab (ig 3 ), and during the summer from the darker colours: Tawny Olive (i e 3), Cinnamon (i c 3), Vinaceous Buff (e c 3) and light Ochraceous Buff (e a 3).

The coloration of the fur of the tail, fore and hind legs does not differ from that given in the description by $\mathrm{Ognev}$ (1940) and Korneyev (1960).

Both these authors discuss in fairly great detail the scale of differences in the colour of each part of the body during the summer and winter periods. They both find that all the colours become lighter with the approach of winter.

In view of the fact that $\mathrm{Ognev}$ used the $\mathrm{Ridgway}$ (1912) scale in giving certain of his colours, it proved possible to establish that the coloration of his summer material did not differ from that observed in the material used for the present study. Unfortunately $\mathrm{O} g \mathrm{n}$ e $\mathrm{v}$ did not in every case give descriptions of the colour of hair according to $\mathrm{Ridgway}$, and it is therefore impossible to make a full comparison of the coloration of the hare from the Moscow region (Soviet Union) with that from the Poznan province (Poland). In the case of the winter material it is clear from comparison of the colours given that the hares from the Moscow district are lighter in colour than hares from Poland. This fact may be connected with different climatological condition of both regions (compare e. g. Wostson, 1963).

According to Ognev (1940) and Korneyev (1960) the coloration of the back of hares both in winter and summer, is tawny-yellowish-clayey-black, the ratio of the shades and colours to each other exhibiting considerable individual variation both at the same time and during the season.

It must be mentioned that greatest variations in seasonal coloration occurs in the occipito-nuchal region, then the caudal part of the body and the sides, the least variation being exhibited by the back (Fig. $2 \mathrm{~A}-\mathrm{D})$.

\section{Moulting}

On account of the fact that moulting in the European hare never takes place simultaneously over the whole of its body, as is often the case with a large number of mammals, eight zones of moulting were 
distinguished (Fig. 1). This division is justified by the differences in the density and length of the hair and the differences in its colour.

The change in coat in the spring and autumn takes place in the following order: 1. back, 2. upper chest, 3. head, ears and occipitonuchal region, and finally 4 . sides and belly. It is thus similar to the subdorsal type described by $\mathrm{Kryltzov}$ (1962). Moulting takes place in patches (tufts) and it is only in a few hares (primarily young ones) that a whole zone may moult simultaneously.

The patch process of moulting takes place in such a way that in a given zone of the body more or less numerous spots are formed on which the old hair falls out and the new hair grows. These patches fuse

Table 1.

The moulting process in the European hare.

\begin{tabular}{|c|c|c|c|c|c|c|c|c|c|c|c|c|c|c|c|}
\hline Year \& Montn & 1950 & \multicolumn{12}{|c|}{1959} & \multicolumn{2}{|c|}{1960} \\
\hline 2ones of moulting & $x_{11}$ & I & 11 & 111 & IV & $v$ & v1 & viI & vi11 & $1 \mathrm{x}$ & $x$ & $x_{1}$ & $\mathrm{x} 11$ & 1 & II \\
\hline 1. Back & & & $\mathbb{P}$ & $\boxplus$ & (x) & 27. & se & (H) & (11) & 进 & $\theta$ & D & & & $\oplus$ \\
\hline IV - Upper ohest and neok & & & & (L) & $\uplus$ & & & (1) & (1) & & $\bigoplus$ & (1) & & & \\
\hline$v$ - Ocoiplto-nuehal region & & & & $\oplus$ & $\oplus$ & & & & & & (1) & & & & \\
\hline v1 - Head & & & & (1) & $\oplus$ & & & & & & (1) & 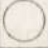 & & & \\
\hline V11 - Ears & & & & & 世 & & & ) & & & (1) & & & & \\
\hline II - sides & & & & & (1) & & & 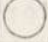 & & & $\theta$ & & & & \\
\hline vill - Scapulae and lumbar region & & & & & & & & & & & $\bigoplus$ & & & & \\
\hline $111-\operatorname{sec11y}$ & & & & & (1) & & & & & & O & J & & & \\
\hline Number of skins examined & 7 & 52 & 47 & 50 & 55 & 52 & 22 & 23 & 42 & 51 & 46 & 4 & 40 & 37 & 46 \\
\hline
\end{tabular}

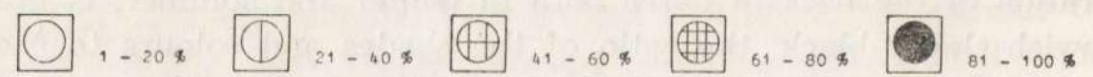

into larger areas as the process progresses, or even cover a whole zone. In this latter case the height of the growing hair is not even and in this way reveals the type of moult referred to. In young hares in the first calendar year of their lives the hair grows evenly within a whole zone.

Moulting processes do not occur only in December and January, hares always being encountered in the other months, in which moulting is taking place to a lesser or greater degree. Change of coat on the back in patches and as whole zone have been treated jointly in the diagrams. Despite the fact that the percentage of moulting individuals here in 
July and August does not fall below 50, the spring intensification in this process occurs in April (about 95\%), and the autumn in September (about $69^{\%} \%$ ). The winter hair on the back, with the growth of the summer fur in the spring, becomes brittle and gradually splits, beginning with the ends of the hairs, thus altering the colour of the animal (Fig. $2 \mathrm{~A}$ ). In the remaining parts of the body intensification of moulting always takes place in April and October. The back therefore begins to moult earlier than the other zones of the body in both spring and autumn (Table 1). The belly moults in the same way as the sides and upper chest, but here, on account of the white colour of the hair, it wa: more difficult to trace this process.

As from the early spring, and even from the end of the winter, the skin of the hare, until the winter fur grows, is thickened, plump and has a distinctly dark, almost grey colour characteristic of animals in process of changing their coats. During the winter (between moults) the skin is light in colour, thin and typical of animals not in process of moulting. Hares may sporadically be found, on the back and sides of which traces of growing hair can be found even during this period, this taking place on small areas of $1-5 \mathrm{~cm}^{2}$, round in shape or taking form of a lengthways stripe along the body. It is characteristic of this phenomenon that the hair does not grow in the way it normally does under the cover of the old fur, but directly on the hare skin. These are injured places, or places scraped clean of fur when the hare squeezed through thorny bushes, or barbed wire fences, or

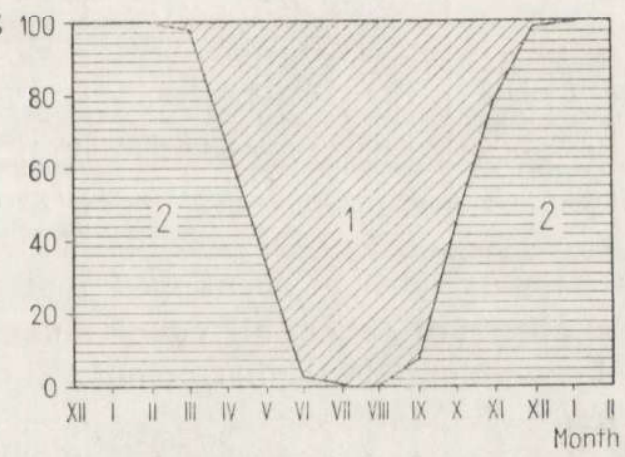

Fig. 3. Percentage of winter fur. were possibly caused during fights with small predators. These scratches are most often due in males to fighting, while in females they are caused during copulation. Such phenomena cannot of course be treated as moulting (Butcher, 1959).

The occurrence of the winter hair in the yearly cycle is shown in figure 3. It can be seen from this that $100 \%$ of hares with winter coats are encountered only from December to February. In March about $3 \%$ of the animals already have their summer coat, and in June there are only traces (tufts) of winter hair on certain of the individuals. In July and August all the hares have summer coats. In September we again 
have about $8 \%$ of individuals which have already changed to their winter coats.

K or neyev (1960) considers the changes in the skin taking place uninterruptedly from the spring to the autumn as the most important character of moulting. It is true that no hares are encountered during this period in which moulting processes are not taking place in some part of their bodies, whether this is in patches, large areas or even whole zones of the body, yet as shown by our observations, there are two distinct periods of intensification in the change in coat - the spring (February-June) and the autumn (September-November). The first of these leads in the spring to the replacement of the winter coat by the summer, the second - the summer coat by the winter. It is therefore impossible to agree with the view held by Korneye v (1960) that there is only one moult in the hare.

Table 2.

Extreme lengths of hair in $L$. europaeus in $\mathrm{mm}$.

\begin{tabular}{|c|c|c|c|c|c|c|c|c|c|}
\hline & \multicolumn{6}{|c|}{ Poznań province } & \multirow{2}{*}{\multicolumn{3}{|c|}{$\begin{array}{l}\text { B1aryst ok province } \\
\text { Necember } 1959- \\
\text { January } 1950\end{array}$}} \\
\hline & \multicolumn{3}{|c|}{ July - kugust 1959} & \multicolumn{3}{|c|}{ January 1959} & & & \\
\hline & Guard & Pile & Fur & Guard & P1le & Fur & Guard & Pile & Fur \\
\hline I - Back & $32-45$ & $21-35$ & $9-20$ & $36-52$ & $24-37$ & $10-24$ & $34-55$ & $25-38$ & $13-25$ \\
\hline II - Sides & $26-50$ & $17-35$ & $9-22$ & $40-61$ & $25-40$ & $15-25$ & $34-66$ & $24-41$ & $15-26$ \\
\hline 111 - Be11y & $20-40$ & $14-35$ & $8-23$ & $35-52$ & $28-43$ & $18-32$ & $39-60$ & $28-47$ & $16-35$ \\
\hline $\begin{array}{l}\text { IV - Wpper } \\
\text { chest }\end{array}$ & $28-58$ & $20-40$ & $15-25$ & $45-54$ & $30-48$ & $18-31$ & $40-68$ & $25-52$ & $17-32$ \\
\hline
\end{tabular}

It must also be mentioned that the individuals which moult in the summer are almost all young animals. It is known from the studies by H ew son (1963), that young hares undergo two moults before reaching their winter coat.

A general change in coloration is connected with the moult. The spring moult causes the lighter tones of the winter coat to aisappear in favour of the distinctly darker summer coloration. During the autumn moult the coat takes on lighter colours, as the winter fur grows.

\section{Lenght and Density of Fur}

The extreme lengths of hairs from different zones of the body are given in table 2, and their mean length in Fig. $4^{2}$ ).

The longest guard hair from the winter period, $72 \mathrm{~mm}$ in length, was

2) It must be emphasised that no significant difference was found between measurements of the hairs given in this table, for which series of 30 specimens $\left(15 \sigma^{7} \sigma^{7}\right.$ ond 15 of $q$ ) were measured, when compared with the measurements of hairs made initially from series of 10 specimens ( $5 \sigma^{7} \sigma^{x}$ and 5 우 + ). 
found in the anal region. Toldt (1935 - page 162, Fig. 34) states that the length of the pile hair on the back of L. europaeus is $42 \mathrm{~mm}$. In our case the length of the guard hair on the back during the winter period was approximately $42 \mathrm{~mm}$, when the pile hair measures on an average about $31 \mathrm{~mm}$. The shortest hairs from the summer period, measuring $2-3 \mathrm{~mm}$ were found on the ears.

As can be seen from the measurements, no significant differences were found in the length of hair of males and females.

Comparison of the length of the winter hair of hares from the Poznan and Białystok province did not reveal the differences which had

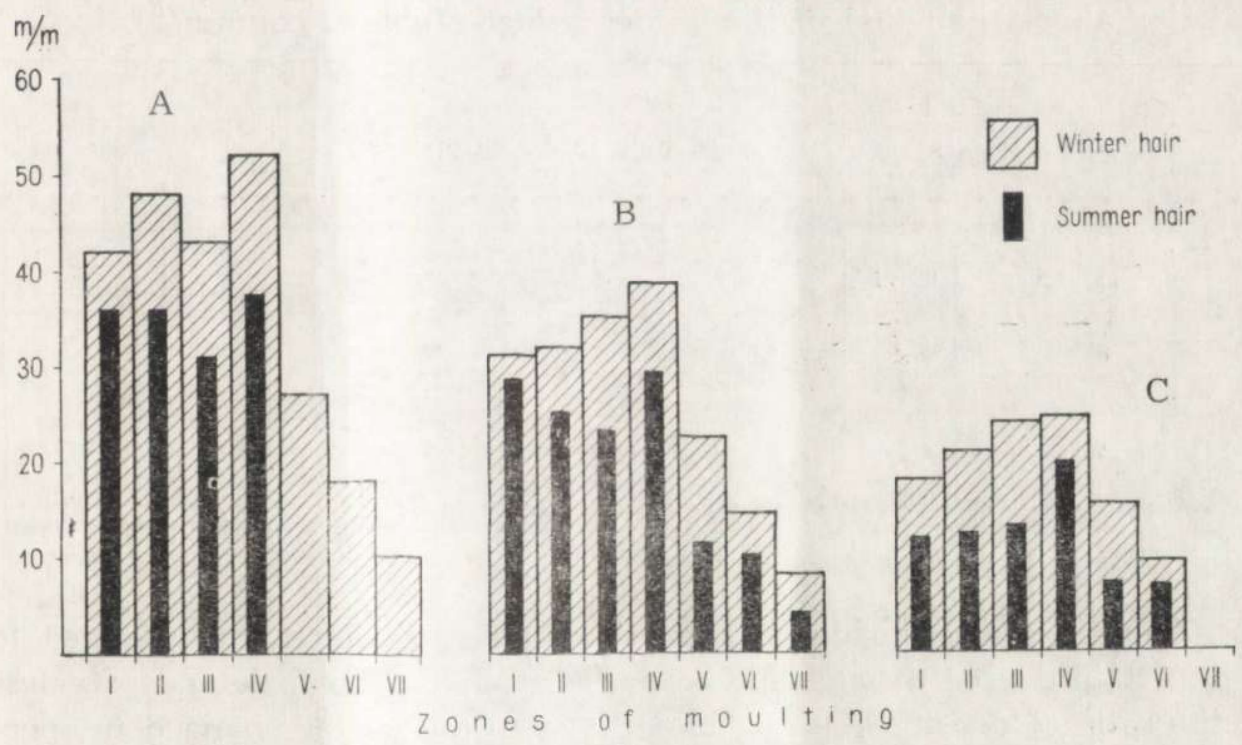

Fig. 4. Mean length of hairs in European hare.

A - guard hair; B - pile hair; C - fur.

been anticipated (Table 2). The winter (January 1959) and summer (July 1959) hair of the Poznan hare only were therefore given in Fig. 4.

The pile hair on the back from the occiput as far as the grey part above the tail is more or less wavy. It is only in the winter that about $5 \%$ of hares are encountered with almost smooth coats.

Cerevitinov (1958), in investigating the topography of the hair of fur- bearing animals, classified the hare with "abdominal" animals i.e. according to his nomenclature animals in which the length of the hair decreases from the abdomen in all directions. Confirmation of this is to be found in the data on length of hair, particularly during the winter period (Table 2). 
The distribution of hair on the hare's skin is squamose in type ( $\mathrm{T} \mathrm{ra} \mathrm{u} \mathrm{t-}$ mann \& Fiebiger, 1954). The hair grows in groups of 3 tufts (rarely 2-4). The groups are arranged in series across the animal's body, the groups of each adjacent series being situated in the intervals between the groups of the first series. There is pile hair in almost each group, but this is not invariable. Very rarely there is guard hair. The majority of the groups consist of the fur. In certain specimens the groups are found to combine in integrated series.

The density of the fur of hares shot in the winter in the Poznan and Białystok provinces is almost identical. Specimens from the Poznan area in July have a less dense fur than they have in winter, density being almost half that of the winter pelage (Table 3, column c).

Table 3.

Density of hair in $L$. europaeus.

\begin{tabular}{|l|l|c|c|c|c|c|}
\hline Zones of moulting: & Wonth & $\begin{array}{c}\text { I } \\
\text { Back }\end{array}$ & $\begin{array}{c}\text { II } \\
\text { SIdes }\end{array}$ & $\begin{array}{c}\text { III } \\
\text { Belly }\end{array}$ & $\begin{array}{c}\text { IV } \\
\text { Upper chest }\end{array}$ & $\begin{array}{c}\text { Oocipito- } \\
\text { nuchaI } \\
\text { region }\end{array}$ \\
\hline No. of groups & July & 43 & 45 & 46 & 41 & - \\
per 25 ma & January & 42 & 40 & 40 & 42 & 48 \\
No. of hairs in & July & $40-50$ & $35-45$ & $15-20$ & $15-25$ & - \\
Eroup /3 tufts/ & January & $40-90$ & $35-60$ & $30-60$ & $40-70$ & $40-50$ \\
Counted number of & July & $6880-8600$ & $6300-8100$ & $2750-3680$ & $2460-4100$ & - \\
hairs per $1 \mathrm{~cm}^{2}$ & Jantary & $6720-15120$ & $5600-9600$ & $4800-9500$ & $6720-11760$ & $7680-9500$ \\
\hline
\end{tabular}

Countings were made on skin, the surface of which was changed to a certain degree through having been left to dry on forks, nevertheless the ratio of density of the summer coat to the winter changed in specimens from the Poznan province, similarly to that in hares from Tibet [Lepus (Eulagus) tibetanus $\mathrm{W}$ a te $\mathrm{rhouse}$ (P e r e valov, 1956) in a ratio of $1: 2-2.5$. In the case of Sorex araneus $L$. this ratio is $1: 1.3$ (Bor ow ski, 1959).

The guard hair on the occipito-nuchal regions, head and ears is so scanty during the summer that, practically speaking, it does not play a protective role during this time (about 1 hair per $1-2 \mathrm{~cm}$ ). The underfur was not found to occur on the ears.

\section{CONCLUSIONS}

1. The hair of the European hare, with the exception of the belly, is variegated. The length of the different colour sections varies from 5 to $10 \mathrm{~mm}$.

2. The coloration of the hare exhibits considerable individual and seasonal variations. The lighter colours of the winter fur change to darker summer colours 
after the spring moult, and the reverse applies after the autumn moult. Colours of the winter fur change to darker summer colours after the spring moult, and the reverse applies after the autumn moult. The greatest variations in coloration are exhibited by the occipitonuchal region, the caudal part of the body and sides; the least by the back and head, while almost no variation occurs in the colour of the ears, belly and limbs.

3. From February to November inclusively the presence of colour and structural changes was found in the skin of hares. During the remaining months no specimens in moult were encountered.

4. The order in which the zones of the body moult in the spring and autumn begins from the back (in patches), then the upper chest; this is followed by almost simultaneous moulting of the occipito-nuchal area, the head and ears, and finally the sides, belly, scapulae and lumbar region. In the majority of hares the back moults almost completely in the autumn.

Despite the zonal system of moulting, it is only at the beginning of the spring moulting period that patch-like darkening of the skin can be observed. Later on, up to November inclusively, the whole skin is dark and plum, despite the fact that change of hair occurs, usually in patches, and chiefly on the back.

5. The European hare has distinctly defined periods of spring and autumn moults. The spring moulting period continues up to the end of June (main point in April), while the growth of the winter fur lasts for a very long time (main point in October) and may begin as early as July. These are specimens which already have their winter coat in September.

6. The density and length of the hair differ in different zones of the body: the hair is scantier and shorter in the summer, and longer and denser in the winter.

7. The summer coat of hares from the Poznan province does not differ from that of specimens from Bialystok province, while the winter coat of the hares from the Bialystok area is slightly lighter in colour than that of hares from the Poznań province.

Acknowledgments: I should like to put on record my gratitude to one who is no longer alive to receive it, Professor A. D e h nel, for having initiated and guided the work forming the basis of the present study.

\section{REFERENCES}

1. Bider, J. R., 1961: An ecological study of the hare Lepus americanus. Can. J. Zool., 39, $1: 81-103$.

2. Borowski, S., 1959: Variations in density of coat during the life cycle of Sorex araneus araneus L. Acta theriol., 2. 14: 286-289.

3. Butcher, E. O., 1959: Restitutive growth in the hair follicle of the rat. Ann. N. Y. Acad. Sci., 83, $3: 369-377$.

4. Cerevitinov, B. F., 1958: Topografičeskie osobennosti volosianogo pokrova pušnyh zverej. Tr. Vsesoj. N.-i. in-ta žyvotn. syria i pušn., $17: 256-307$.

5. Couturier, M., 1955: Das Haarkleid des Alpenschneehasen Lepus timidus varronis Mille r. 1901. Z. Jagdwiss., 1, 1. Hamburg.

6. Dimidov, P. G. \& Popov, M. V., 1961: O srokah i haraktere linki zajca belaka v Jakutii. Nauč. Soobšč, Jakutskij fil., Sib. otd., AN SSSR, $5: 95-99$. 
7. Gedymin, J., 1954: Rozwojowe i sezonowe zmiany owłosienia królilkólików ras futerkowych. Pozn. Tow. Przyj. Nauk, Prace Kom. Nauk Roln. i Leeśnteśn., 2, $5: 1-52$.

8. Gerasimova, M. A., 1955: Tovarnye svojstva škurok zajca rusaka aklimalimatizirovannogo v Sibiri. Tr. Vsesoj. n.-i. in-ta ohotn. promysla, 15: 23-37. 7.

9. Gerasimova, M. A., 1955: Osennaja linka zajca rusaka. Tr. Vsesoj. m.- n.-i. in-ta ohotn. promysla, 15: $38-58$.

10. Hewson, R., 1961: Collars for marking mountain hares, J. Wildl. Mmgtngt., $25,3: 329-331$.

11. Hewson, R., 1963: Moult and pelages in the brown hare Lepus europaieuaeus occidentalis de Winton. Proc. zool. Soc. Lond., 141, 4:677-688.

12. Korne yev, O. P., 1960: Zajec rusak na Ukraini. Vidavn. Kiivskogo Univ.liv., $1-108$, Kiiv.

13 Kryltzov, A. I., 1962: Topografija linki gryzunov i vozmožnost ispolzorva-Vanija ee $\mathrm{v}$ kačestvie taksonomičeskogo priznaka Tr. n.-i. in-ta zašč, rastast. Kaz. SSR. 7: 418-451.

14. Lind, E. A., 1961: On the occurrence daily activity, and spring moult of thethe snow hare (Lepus timidus) at Kilpisjärvi in Enontekiö. Suomen Riistașta, 14: 106-111.

15. O gnev, S. I., 1940: Zvery SSSR i priležaščih stran. Gryzuny 4: 106-28484 AN SSSR, Moskva-Leningrad.

16. Ostwald, W., 1939: Die Kleine Farbmesstafel. Ausgabe C. "Musterschmidt".t". Wiss. Verl. Göttingen, Frankfurt-Berlin: 1-10.

17. Perevalov, A. A., 1956: Strojenije meha i linka zajca peščanika. Uč. J̌. Zap. Tiraspolsk. ped. in-ta, 1.

18. Stein, G. H. W., 1958: Die Feldmaus. A. Ziemsen Verl. Wittenberg: 1-76. 6.

19. Toldt, K., 1935: Aufbau und natürliche Färbung des Haarkleides der Wild ld Säugetiere. D. Ges. Kleintier- u. Pelztier. 1-291: Leipzig.

20. Trautmann, A. \& Fi e biger, J., 1954: Histologia i mikroskopowa a anatomia porównawcza zwierząt domowych. PWRiL, 1-517: Warszawa.

21. Wasts on, A., 1963: The effect of climate on the colour changes of moun- tain hares in Scotland. Proc. zool. Soc. Lond., 141, 4: 823-835.

22. Zimmerm a n n, K., 1952: Vergleichende Farbtabellen. Verl. Paul Schops: : 1-47: Frankfurt/Main.

Polish Academy of Sciences, Mammals Research Institute, Białowieża, Poland.

\section{STRESZCZENIE}

Przebadano 611 skór zająca szaraka, Lepus europaeus Pallas, 1778, zebranych w pełnym cyklu rocznym w woj. poznańskim i 28 zimowych skór z woj. białostockiego. Stwierdzono, że ubarwienie zająca szaraka wykazuje dużą zmienność indywidualną i sezonową. Włos jego, poza brzuchem, jest wielobarwny. Jaśniejsze ubarwienie zimowe przechodzi w ciemniejsze letnie (Ryc. 2 A-D). 
Ubarwienie letnie nie różni się u zajęcy z województw: poznańskiego i białostockiego. Natomiast włos zimowy u tych ostatnich jest nieznacznie jaśniejszy.

Największą sezonową zmienność ubarwienia wykazuje potylica i kark, ty! i boki ciała. Ubarwienie uszu, brzucha i kończyn prawie nie ulega zmianom.

Zając szarak zmienia sierść dwa razy w ciągu roku: od lutego do maja i od września do listopada włącznie. Zciemnienie skóry przy lince wiosennej ustępuje dopiero po zakończeniu linki jesiennej. W okresie całego lata u osobników starych skóra jest ciemna. Osobniki młode przed linką juvenilną mają skórę jasną.

Linka nie przebiega równomiernie na calym ciele (Tabela 1, Ryc. 1) i zarówno wiosną jak i jesienią postępuje od grzbietu (plamami) przez przedpiersie, glowę, uszy i potylicę, kark, sehodzi na łopatki, lędźwie i boki, a kończy się na brzuchu. Nasilenie linki wiosennej przypada w kwietniu. W ciągu miesięcy letnich u ca $50 \%$ osobników grzbiet, przedpiersie i boki linieją plamami. Jesienne nasilenie linki prawie na całym ciele ma miejsce w październiku. Grzbiet zaczyna jednak linieć już około 4 tygodnie wcześniej. Większość osobników (ca $60 \%$ ) jesienią ma na grzbiecie linkę całkowitą.

Gęstość sierści jest różna w różnych okolicach ciała, przy czym wszędzie włos jest gęściejszy zimą niż latem (Tabela 3 ).

Długość włosa zimą jest większa niż latem i zmienna w różnych okolicach ciała (Tabela 2, Ryc. 4).

Sierść na grzbiecie zająca jest mniej lub więcej pofalowana. U około $5 \%$ osobników zimowych jest prawie gładka. Około $10 \%$ zajęcy ma białą gwiazdkę na czole. 